\title{
Prevalence and Factors Associated with Microalbuminuria among Type 2 Diabetic Patients : A Hospital Based Study
}

\author{
Bikram Khadka, ${ }^{1}$ Mohan Lal Tiwari, ${ }^{2}$ Binod Timalsina, ${ }^{3}$ Prabodh Risal, ${ }^{4}$ Suprita Gupta, ${ }^{5}$ Dilaram Acharya ${ }^{6,7}$
}

'Department of Biochemistry, Devdaha Medical College and Research Institute, Devdaha, Rupandehi, Nepal, ${ }^{2}$ Department of Internal Medicine, Devdaha Medical College and Research Institute, Devdaha, Rupandehi, Nepal, ${ }^{3}$ Department of Anatomy, Devdaha Medical College and Research Institute, Devdaha, Rupandehi, Nepal, ${ }^{4}$ Department of Biochemistry, Kathmandu University, School of Medical Sciences, Dhulikhel, Nepal, ${ }^{5}$ Department of Biochemistry, National Medical College and Teaching Hospital, Birgunj, Nepal, ${ }^{6}$ Department of Preventive Medicine, College of Medicine, Dongguk University, Republic of Korea, ${ }^{7}$ Department of Community Medicine, Devdaha Medical College and Research Institute, Devdaha, Rupandehi, Nepal.

\section{ABSTRACT}

Introduction: Microalbuminuria is the earliest clinical evidence of diabetic nephropathy. However, prevalence and associated factors with microalbuminuria among type 2 diabetic patients has been understudied area of research in Nepalese context. This study aimed to determine the prevalence and factors associated with microalbuminuria among type 2 diabetic patients.

Methods: This study was a hospital-based cross-sectional study. Blood samples for serum creatinine, Hemoglobin A1C, Fasting blood sugar and urine sample for microalbumin and urine creatinine were collected and analyzed using validated and standardized tools from a total of 400 Type 2 diabetic patients in Devdaha Medical College and Teaching Hospital, Rupandehi, Nepal from August 2014 to September 2017. Microalbuminuria was defined as urinary albumin-to-creatinine ratio greater than 30 and less than $300 \mu \mathrm{g} / \mathrm{mg}$ of creatinine

Results: Of 400 type 2 diabetic patients, 186 (46.5\%) had microalbuminuria. The mean values of FBS, HbA1C, serum creatinine, microalbumin, microalbumin/urine creatinine ratio were higher in microalbuminuria group. Microalbuminuria was significantly positively correlated with duration of diabetes, FBS, HbA1C, serum creatinine, microalbumin, microalbumin/ urine creatinine, systolic blood pressure and diastolic blood pressure $(\mathrm{P}<0.01)$.

Conclusions: Our study demonstrated that nearly half of the type 2 diabetic patients had microalbuminuria. Our results emphasize to increase to accessibility to microalbuminuria testing for all the type 2 diabetic patients and bring them under medical supervision to reduce the unwanted complications of diabetes mellitus.

Keywords: diabetic nephropathy; microalbumin; microalbumin creatinine ratio; microalbuminuria; type 2 diabetes mellitus.

\section{INTRODUCTION}

Type 2 diabetes mellitus (T2DM) and its complications has been a major public health concern worldwide. ${ }^{1}$ In 2013, International diabetes federation (IDF) reported that about 382 million people suffered from diabetes globally. ${ }^{2}$ Among the diabetic patients, $20-40 \%$ are the victims of diabetic nephropathy and $10-20 \%$ of them die due to kidney failure in T2DM..$^{3,4}$ Microalbuminuria (MA) is the earliest clinical evidence of diabetic nephropathy..$^{5,6}$

Studies from Nepal reported a prevalence of 6.3 to

Correspondence: Bikram Khadka, Department of Biochemistry, Devdaha Medical College and Research Institute, Devdaha, Rupandehi, Nepal. Email: bikram87khadka@gmail.com, Phone: +977. 9857039169. 
Khadka et al. Prevalence and Factors Associated with Microalbuminuria among Type 2 Diabetic Patients

$8.5 \%$ of diabetes mellitus in different community, ${ }^{4,7}$ while Maharjan B et.al demonstrated $49.05 \%$ type 2 diabetic patients had microalbuminuria. ${ }^{8}$ Given that MA is associated with high blood pressure, dyslipidemia, inflammation and endothelial dysfunction. ${ }^{9}$ However, the prevalence and associated factors of microalbuminuria in T2DM is less understood in Nepal.

This study aimed to determine the prevalence and factors associated with microalbuminuria among type 2 diabetic patients.

\section{METHODS}

A cross-sectional study was conducted at Devdaha Medical College and Research Institute on systematic random sample of T2DM attending Medical OPD during the period of August 2014 to September 2017. A total of 400 study participants with T2DM with the age of more than 39 years were involved in this study. A sample size of 200 T2DM were involved in the study based on the one of the study finding from Nepal demonstrated $23 \%$ overall prevalence of nephropathy in T2DM. ${ }^{10}$

The ethical committee of Devdaha Medical College and Research Institute approved the study protocol. A written informed consent was obtained from the study participants and personal identifiers were removed before data analysis.

Variables like age, sex, duration of T2DM and smoking habit were obtained using comprehensive questionnaire filled through direct interview among the study participants. Anthropometric measurements like weight, height, body mass index (BMI) and blood pressure were measured. BMI of each individual was calculated as their weight $(\mathrm{kg})$ divided by the square of their height $\left(\mathrm{m}^{2}\right)$. Smoking habit was noted as yes if the participant smoked at least one cigarette per day. Diagnosis of T2DM was done according to the criteria of American Diabetes Association. ${ }^{11}$

Laboratory parameters include Fasting blood sugar, HbA1C, Serum creatinine, Microalbumin and microalbumin/urine creatinine ratio in urine. Venous blood collected in a gel tube was allowed to clot for estimation of FBS and serum creatinine whereas Ethylene Diamine Tetra Acetic Acid (EDTA) was used for $\mathrm{HbA1C}$. Random spot urine sample was collected for microalbumin and urine creatinine. Fasting blood sugar, serum creatinine and urine creatinine was estimated using enzymatic methods by ERBA Chem 5 V3 semiautomated chemistry analyzer where as $\mathrm{HbA} 1 \mathrm{C}$ and microalbumin was estimated using nephelometry methods by mispa-i3 from Agappe diagnostics.
Subjects with Type 1 DM, T2DM undergoing dialysis, macroalbuminuria, known case of renal failure, nephrotic syndrome, urinary tract infection, haematuria, ketonuria, pregnancy, heart failure, vigorous exercise before collecting the sample and use of systemic steroids in past four weeks were excluded.

The observed data were tabulated in MS Excel 2007 and further statistical analysis was performed by using SPSS 20. The ages were categorized under three subgroups as $<50$ years, $50-59$ years and $\geq 60$ years. Blood pressure was subdivided as normotensive for systolic $(80-120 \mathrm{mmHg})$ and diastolic $(60-80 \mathrm{mmHg})$ whereas hypertensive was categorized as systolic $>120 \mathrm{mmHg}$ and diastolic $>80 \mathrm{mmHg}$. The descriptive statistics (frequency, mean, SD) were calculated using the study variables. The study population was categorized on the basis of level of microalbumin/urine creatinine ration as $<30 \mu \mathrm{g} / \mathrm{mg}$ of creatinine (Without microalbuminuria) and $30-299 \mu \mathrm{g} / \mathrm{mg}$ of creatinine as with microalbuminuria. Students t-test was performed to find the significant differences between the variables. Correlation coefficients were calculated to find the differences between the study variables.

\section{RESULTS}

Of 400 study participants, slightly more than half $(52.8 \%)$ were male, nearly three fourth $(73.3 \%)$ were above 50 years of age, and more than half (56.2\%) were non-smokers. Mean \pm SD of duration of diabetes in years and $\mathrm{BMI}\left(\mathrm{kg} / \mathrm{m}^{2}\right)$ were $5.38 \pm 3.60$ and $32.62 \pm 5.99$, respectively. Mean \pm SD systolic and diastolic blood pressure measurements were $126.77 \pm 16.07 \mathrm{mmHg}$ and $87.86 \pm 11.48 \mathrm{mmHg}$, respectively.

\begin{tabular}{|c|c|c|}
\hline Variables & n (\%) & Mean \pm SD \\
\hline \multicolumn{3}{|l|}{ Sex } \\
\hline Male & $211(52.8)$ & - \\
\hline Female & $189(47.2)$ & - \\
\hline \multicolumn{3}{|l|}{ Age (years) } \\
\hline$<50$ & $107(26.8)$ & $45.85 \pm 2.65$ \\
\hline $50-59$ & $155(38.8)$ & $54.27 \pm 2.53$ \\
\hline $60 \geq$ & $138(34.5)$ & $65.31 \pm 3.97$ \\
\hline \multicolumn{3}{|l|}{ Smoking habit } \\
\hline Yes & $175(43.8)$ & - \\
\hline No & $225(56.2)$ & - \\
\hline $\begin{array}{l}\text { Duration of } \\
\text { diabetes(in years) }\end{array}$ & - & $5.38 \pm 3.60$ \\
\hline $\begin{array}{l}\text { Blood pressure } \\
\text { measurement } \\
(\mathrm{mmHg})\end{array}$ & & \\
\hline
\end{tabular}




\begin{tabular}{|lcc|} 
Systolic & - & $126.77 \pm 16.07$ \\
Diastolic & - & $87.86 \pm 11.48$ \\
Body mass & - & $32.62 \pm 5.99$ \\
index(BMI) in kg/m & & \\
\hline
\end{tabular}

Table 2 demonstrates the comparisons of personal profile of the study participants with or without microalbuminuria. Systolic hypertensive, diastolic hypertensive, body mass index, diabetes duration and age group of study participants had higher in microalbuminuria group compared with normoalbuminuria group. Smoking habit and gender characteristics were similar in both groups.

\begin{tabular}{|c|c|c|c|c|}
\hline \multirow[t]{2}{*}{ Variables } & \multirow{2}{*}{$\begin{array}{c}\text { Without } \\
\text { microalbuminuria } \\
(\mathrm{n}=214)(53.5 \%) \\
\mathrm{n}(\%)\end{array}$} & \multicolumn{3}{|c|}{$\begin{array}{l}\text { With microalbuminuria } \\
(\mathrm{n}=186)(46.5 \%)\end{array}$} \\
\hline & & Mean \pm SD & n (\%) & Mean \pm SD \\
\hline \multicolumn{5}{|l|}{ Gender } \\
\hline Male & $123(57.5)$ & - & $88(47.3)$ & - \\
\hline Female & $91(42.5)$ & - & $98(52.7)$ & - \\
\hline \multicolumn{5}{|l|}{ Age group(years) } \\
\hline$<50$ & $82(38.3)$ & $45.68 \pm 2.55$ & $25(13.4)$ & $46.40 \pm 2.97$ \\
\hline $50-59$ & $93(43.5)$ & $53.37 \pm 1.87$ & $62(33.3)$ & $55.62 \pm 2.78$ \\
\hline$\geq 60$ & $39(18.2)$ & $64.76 \pm 3.37$ & $99(53.2)$ & $65.52 \pm 4.18$ \\
\hline $\begin{array}{l}\text { Duration of diabetes (in } \\
\text { years) }\end{array}$ & - & $3.66 \pm 2.44$ & & $7.36 \pm 3.70$ \\
\hline \multicolumn{5}{|l|}{$\begin{array}{l}\text { Blood pressure } \\
\text { measurements }(\mathrm{mmHg})\end{array}$} \\
\hline \multicolumn{5}{|l|}{ Systolic } \\
\hline Normotensive & $127(59.34)$ & $111.22 \pm 7.75$ & $47(25.26)$ & $115.74 \pm 6.07$ \\
\hline Hypertensive & $87(40.65)$ & $131.15 \pm 7.18$ & $139(74.74)$ & $141.98 \pm 11.78$ \\
\hline \multicolumn{5}{|l|}{ Diastolic } \\
\hline Normotensive & $98(45.79)$ & $74.03 \pm 5.05$ & $29(15.59)$ & $77.58 \pm 4.35$ \\
\hline Hypertensive & $116(54.21)$ & $90.56 \pm 6.03$ & $157(84.41)$ & $96.40 \pm 8.52$ \\
\hline $\begin{array}{l}\text { Body mass index(BMI) }(\mathrm{kg} / \\
\left.\mathrm{m}^{2}\right)\end{array}$ & - & $31.75 \pm 5.91$ & - & $33.62 \pm 5.95$ \\
\hline \multicolumn{5}{|l|}{ Smoking habits } \\
\hline Yes & 94 (43.9) & - & $81(43.5)$ & - \\
\hline No & $120(56.1)$ & - & $105(56.5)$ & - \\
\hline
\end{tabular}

The differentials of laboratory variables between microalbuminuria and normoalbuminuria group has been presented (Table 3). The mean values of FBS, HbA1C, serum creatinine, microalbumin, microalbumin/urine creatinine ratio were higher in microalbuminuria and found statistically significant difference $(P<0.05)$ 


\begin{tabular}{|c|c|c|c|c|}
\hline \multirow[t]{2}{*}{ Variables } & $\begin{array}{l}\text { Without microalbuminuria } \\
\qquad(\mathrm{n}=214)\end{array}$ & $\begin{array}{l}\text { With microalbuminuria } \\
\qquad(\mathrm{n}=186)\end{array}$ & t-value & P value \\
\hline & Mean \pm SD & Mean \pm SD & & \\
\hline FBS (mg/dl) & $165.49 \pm 50.86$ & $202.16 \pm 76.72$ & -5.69 & 0.0001 \\
\hline $\mathrm{HbA} 1 \mathrm{C}(\%)$ & $7.84 \pm 1.93$ & $8.48 \pm 1.81$ & -3.41 & 0.001 \\
\hline Serum creatinine $(\mathrm{mg} / \mathrm{dl})$ & $0.87 \pm 0.16$ & $1.32 \pm 0.33$ & -17.31 & 0.0001 \\
\hline Microalbumin (mg/dl) & $11.15 \pm 6.11$ & $88.63 \pm 74.58$ & -15.14 & 0.0001 \\
\hline $\begin{array}{l}\text { Microalbumin/urine } \\
\text { creatinine ratio }(\mu \mathrm{g} / \mathrm{mg} \\
\text { of creatinine) }\end{array}$ & $19.47 \pm 5.07$ & $119.41 \pm 84.08$ & -17.35 & 0.0001 \\
\hline
\end{tabular}

Microalbuminuria was significantly positively correlated with duration of diabetes, FBS, HbA1C, serum creatinine, microalbumin, microalbumin/ urine creatinine, SBP and DBP $(P<0.01)$ (Table 4).

\begin{tabular}{|c|c|c|c|c|c|c|c|c|c|c|c|c|c|c|c|c|}
\hline \multirow[t]{2}{*}{ Variables } & \multicolumn{2}{|c|}{$\begin{array}{c}\text { Microalbumin/ } \\
\text { urine Creatinine } \\
\text { ( } \mu \mathrm{g} / \mathrm{mg} \text { of } \\
\text { creatinine) }\end{array}$} & \multicolumn{2}{|c|}{$\begin{array}{c}\text { Microalbumin } \\
\text { (mg/dl) }\end{array}$} & \multicolumn{2}{|c|}{$\begin{array}{c}\text { Serum } \\
\text { Creatinine } \\
\text { (mg/dl) }\end{array}$} & \multicolumn{2}{|c|}{$\begin{array}{c}\text { HbA1c } \\
\text { (\%) }\end{array}$} & \multicolumn{2}{|c|}{$\begin{array}{c}\text { FBS } \\
(\mathrm{mg} / \mathrm{dl})\end{array}$} & \multicolumn{2}{|c|}{$\begin{array}{l}\text { Duration of } \\
\text { diabetes } \\
\text { (years) }\end{array}$} & \multicolumn{2}{|c|}{$\begin{array}{c}\text { sBP } \\
(\mathrm{mmHg})\end{array}$} & \multicolumn{2}{|c|}{$\begin{array}{c}\mathrm{dBP} \\
(\mathrm{mmHg})\end{array}$} \\
\hline & $\mathrm{r}$ & $\mathrm{P}$ & $r$ & $P$ & $\mathrm{r}$ & $\mathrm{P}$ & $r$ & $P$ & $r$ & $P$ & $\mathrm{R}$ & $P$ & $r$ & $P$ & $\mathrm{r}$ & $P$ \\
\hline $\begin{array}{c}\text { Duration of } \\
\text { diabetes } \\
\text { (years) }\end{array}$ & 0.733 & 0.000 & 0.679 & 0.000 & 0.642 & 0.000 & 0.112 & 0.025 & 0.124 & 0.013 & - & - & 0.535 & 0.000 & 0.458 & 0.001 \\
\hline FBS (mg /dl) & 0.216 & 0.000 & 0.255 & 0.000 & 0.201 & 0.000 & 0.694 & 0.000 & - & - & 0.124 & 0.013 & 0.171 & 0.001 & 0.165 & 0.102 \\
\hline $\mathrm{HbA} 1 \mathrm{C}(\%)$ & 0.144 & 0.004 & 0.152 & 0.002 & 0.002 & 0.410 & - & - & 0.694 & 0.000 & 0.112 & 0.025 & 0.110 & 0.028 & 0.082 & 0.000 \\
\hline $\begin{array}{l}\text { Serum Creatinine } \\
(\mathrm{mg} / \mathrm{dl})\end{array}$ & 0.754 & 0.000 & 0.678 & 0.000 & - & - & 0.041 & 0.410 & 0.201 & 0.000 & 0.642 & 0.000 & 0.545 & 0.000 & 0.467 & 0.000 \\
\hline $\begin{array}{l}\text { Microalbumin } \\
(\mathrm{mg} / \mathrm{dl})\end{array}$ & 0.928 & 0.000 & - & - & 0.678 & 0.000 & 0.152 & 0.002 & 0.255 & 0.000 & 0.679 & 0.000 & 0.657 & 0.000 & 0.555 & 0.000 \\
\hline $\begin{array}{c}\text { Microalbumin/ } \\
\text { Urine Creatinine } \\
(\mu \mathrm{g} / \mathrm{mg} \text { of } \\
\text { creatinine })\end{array}$ & - & - & 0.928 & 0.000 & 0.754 & 0.000 & 0.144 & 0.004 & 0.216 & 0.000 & 0.733 & 0.000 & 0.663 & 0.000 & 0.563 & 0.000 \\
\hline $\mathrm{SBP}(\mathrm{mmHg})$ & 0.663 & 0.000 & 0.057 & 0.000 & 0.545 & 0.000 & 0.110 & 0.028 & 0.171 & 0.001 & 0.535 & 0.000 & - & - & 0.894 & 0.000 \\
\hline $\mathrm{DBP}(\mathrm{mmHg})$ & 0.563 & 0.000 & 0.585 & 0.000 & 0.467 & 0.000 & 0.082 & 0.102 & 0.165 & 0.001 & 0.458 & 0.000 & 0.894 & 0.000 & - & - \\
\hline
\end{tabular}

r: Pearsonian coefficient, P: significance at $<0.05$ (two tailed)

\section{DISCUSSION}

Our study demonstrated that nearly half of our study participants were microalbuminuric. This finding of our study accords with the study performed in Pokhara, Nepal while, differed other Nepalese study. ${ }^{8,12}$ A number of studies from Bahrain, Oman, India, Korea, Egypt, UAE, Kuwait and Saudi Arabia reported findings similar to our study with some variations in the level of microalbuminuria (MA) among type 2 diabetic patients. ${ }^{13-16}$ However, variability in the prevalence of MA has been reported in some studies from United Kingdom, Mexican Americans, and Pakistan. ${ }^{17-20}$ The variation in the prevalence of microalbuminuria may depend upon several factors like sampling procedure, study settings, socio-demographic factors, and definition of microalbuminuria as well as estimation of microalbumin.

In our study, we found MA was significantly positively correlated with a number of clinical characteristics such as duration of diabetes, FBS, $\mathrm{HbA} 1 \mathrm{C}$, serum creatinine, microalbumin, microalbumin/ urine creatinine, SBP and DBP. Association of duration of diabetes mellitus and age factor with MA has been well documented in many previously published papers. ${ }^{12,14,21-23}$ The logical explanation related to microalbuminuria in aged patients and increased duration of diabetes might be due to the poor glycemic control for longer duration in older age group or the presence of age related atherosclerotic 
changes in the glomeruli.

Similar to our study, other studies ${ }^{24,25}$ also reported an association of clinical characteristics such as FBS, $\mathrm{HbA} 1 \mathrm{C}$, serum creatinine, microalbumin, microalbumin/ urine creatinine, with MA. Likewise, consistent to many other studies ${ }^{26-28}$ our study confirms a positive correlation of MA with systolic and diastolic blood pressure measurements among Type 2 diabetic patients. It is evident that hypertension may increase glomerular filtration pressure that could lead to increased MA due to abnormal glomerular permeability. ${ }^{29}$

Our study has some potential strengths. First, this study has explored a new area of hospital based study among type-2 diabetic patients. Second, this study indicated a need for early identification of MA among diabetic patients, and prevention of hypertension among diabetic patients for a better health outcome. However, we should acknowledge a number of limitations of this study. First, we enrolled a small sample size in this study that limits the generalizability of the study findings. Second, our statistical analyses are too preliminary to report the association of MA with few characteristics. Third, since it is snap-shot study, we cannot establish cause-effect relations. Nonetheless, further studies should understand these limitations of our study.

\section{CONCLUSIONS}

Our study showed nearly half of type 2 diabetic patients had microalbuminuria. Our results emphasize to increase to accessibility to microalbuminuria testing for all the type 2 diabetic patients and would make them to bring under medical supervision and follow up to reduce the unwanted complications of diabetes mellitus. Early diagnosis and the case finding programme in this regard is recommended.

\section{ACKNOWLEDGEMENTS}

We acknowledge to all study participants and all academicians of Devdaha Medical College and Research Institute, Devdaha, Rupandehi, Nepal.

Conflicts of Interest: None.

\section{REFERENCES}

1. King H, Aubert RE, Herman WH. Global burden of diabetes, 1995-2025: prevalence, numerical estimates, and projections. Diabetes care. 1998;21(9):1414-31. [ PubMed | PMC ]

2. International Diabetes Federation. Diabetes atlas sixth edition poster update. Brussels, Belgium 2014. [Full Text]

3. Gu K, Cowie CC, Harris MI. Mortality in adults with and without diabetes in a national cohort of the US population, 1971-1993. Diabetes care. 1998;21(7):1138-45. [PubMed| PMC]

4. Sharma SK, Ghimire A, Radhakrishnan J, Thapa L, Shrestha NR, Paudel N, et al. Prevalence of hypertension, obesity, diabetes, and metabolic syndrome in Nepal. Int J Hypertens. 2011;2011.821971. [PubMed | DOI | Full Text]

5. Cordonnier D, Bayle F, Benhamou P, Milongo R, Zaoui P, Maynard C, et al. Future trends of management of renal failure in diabetics. Kidney Int Suppl. 1993;41:S8. [PubMed ]

6. Lutale JJ, Thordarson H, Abbas ZG, Vetvik K Microalbuminuria among type 1 and type 2 diabetic patients of African origin in Dar Es Salaam, Tanzania. BMC Nephrol. 2007 Jan 15;8:2.[PubMed | DOI | Full Text]

7. Shakya-Vaidya S, Raj Aryal U, Upadhyay M, Krettek A. Do non-communicable diseases such as hypertension and diabetes associate with primary open-angle glaucoma? Insights from a case-control study in Nepal. Glob Health Action. 2013;6(1):22636. [PubMed | DOI]

8. Maharjan B, Bhandary S, Risal P, Sedhain A, Gautam M. Microalbuminuria and macroalbuminuria in type 2 diabetes.
J Nepal Health Res Counc. 2010 Oct;8(2):110-5.[PubMed | PMC]

9. MacIsaac RJ, Cooper ME. Microalbuminuria and diabetic cardiovascular disease. Current Atherosclerosis Reports. 2003;5(5):350-7. [Full Text]

10. Aryal M, Jha B. Assessment of proteinuria as a marker of nephropathy in type 2 diabetes mellitus. Nepal Med Coll J. 2006;8(4):250-3. [PubMed | PMC]

11. Association AD. Erratum. Classification and diagnosis of diabetes. Sec. 2. In Standards of Medical Care in Diabetes-2016. Diabetes care. 2016;39(9):1653. [Full Text]

12. Sigdel M, Rajbhandari N, Basnet S, Nagila A, Basnet $P$, Tamrakar B. Microalbuminuria among type-2 diabetes mellitus patients in Pokhara, Nepal. Nepal Med Coll J. 2008;10(4):242-5. [Full Text]

13. Farahat TM, Elsaeed GK, Gazareen SS, Elsayed TI. Prevalence of proteinuria among type 2 diabetic patients in Menoufia governorate, Egypt. Menoufia Med J. 2014;27(2):363-71. [Ful] Text]

14. Huraib S, Abu-Aisha H, Sulimani RA, Famuyiwa FO, Al-Wakeel J, Askar A, et al. The pattern of diabetic nephropathy among Saudi patients with noninsulindependent diabetes mellitus. Annals of Saudi Medicine. 1995;15(2):120-4. [Full Text]

15. Prashanth P, Sulaiman K, Kadaha G, Bazarjani N, Bakir S, El Jabri K, et al. Prevalence and risk factors for albuminuria among type 2 diabetes mellitus patients: a Middle-East 
perspective. Diabetes Res Clin Pract. 2010;88(3):24-7. [ PubMed | DOI]

16. Abdulrhman A. Prevalence of diabetic nephropathy among Type 2 diabetic patients in some of the Arab countries. Int J Health Sci. 2017;11(1):1-4. [PubMed|PMC]

17. Gatling W, Knight C, Mullee M, Hill R. Microalbuminuria in diabetes: a population study of the prevalence and an assessment of three screening tests. Diabet Med. 1988;5(4):343-7. [PubMed | PMC]

18. Haffner SM, Morales PA, Gruber MK, Hazuda HP, Stern MP. Cardiovascular risk factors in non-insulin-dependent diabetic subjects with microalbuminuria. Arterioscler Thromb Vasc Biol. 1993;13(2):205-10. [Full Text]

19. Marshall S, Alberti K. Comparison of the prevalence and associated features of abnormal albumin excretion in insulin-dependent and non-insulin-dependent diabetes. QJM: An International Journal of Medicine. 1989 Jan;70(1):61-71. [ PubMed | PMC]

20. Wu A, Kong N, De Leon F, Pan C, Tai T, Yeung V, et al. An alarmingly high prevalence of diabetic nephropathy in Asian type 2 diabetic patients: the MicroAlbuminuria Prevalence (MAP) Study. Diabetologia. 2005;48(1):17-26. [ [PubMed | PMC]

21. Modebe O, Masoomi MA. Microalbuminuria and associated factors in Bahraini patients with type 2 diabetes mellitus. Annals of Saudi medicine. 2000;20(2):157-60. [PubMed | $\underline{\mathrm{PMC}]}$

22. Mather H, Chaturvedi N, Kehely A. Comparison of prevalence and risk factors for microalbuminuria in South Asians and Europeans with type 2 diabetes mellitus. Diabetic medicine. 1998;15(8):672-7. [pubMed | PMC]
23. Unnikrishnan R, Rema M, Pradeepa R, Deepa M, Shanthirani CS, Deepa R, et al. Prevalence and risk factors of diabetic nephropathy in an urban south Indian population. Diabetes care. 2007;30(8):2019-24. [PubMed | DOI]

24. Ghosh S, Lyaruu I, Yeates K. Prevalence and factors associated with microalbuminuria in type 2 diabetic patients at a diabetes clinic in northern Tanzania. African Journal of Diabetes Medicine [Internet].2012[cited 2018 Jan 18];20(2). [Full Text]

25. Karar T, Alniwaider RAR, Fattah MA, Al Tamimi W, Alanazi A, Qureshi S. Assessment of microalbuminuria and albumin creatinine ratio in patients with type 2 diabetes mellitus. J Nat Sci Biol Med. 2015;6(1):89-92. [PubMed | DOI | Full Text]

26. Afkhami-Ardekani M, Modarresi M, Amirchaghmaghi E. Prevalence of microalbuminuria and its risk factors in type 2 diabetic patients. Indian J Nephrol. 2008;18:112-7. [PubMed $\downarrow$ Full Text]

27. Lutale JJK, Thordarson H, Abbas ZG, Vetvik K Microalbuminuria among type 1 and type 2 diabetic patients of African origin in Dar Es Salaam, Tanzania. BMC Nephrol. 2007;8:2. [PubMed | DOI | Full Text]

28. Eghan BA, Frempong MT, Adjei-Poku M. Prevalence and predictors of microalbuminuria in patients with diabetes mellitus: a cross-sectional observational study in Kumasi, Ghana. Ethn Dis. 2007;17:726-30. [PubMed | PMC]

29. Mogensen CE. Microalbuminuria and hypertension with focus on type 1 and type 2 diabetes. J Intern Med. 2003;254:45-66. [PubMed | PMC] 